dr inz. Stanisław Mtynarski

mgr inz. Grzegorz Kaczor

Politechnika Krakowska

\title{
Wyznaczanie najsłabszego ogniwa w systemie Common Rail
}

\begin{abstract}
Ksztaltowanie niezawodności złożonych obiektów technicznych jakimi sq układy wtryskowe powinno odbywać sie zarówno na etapie projektowania, wytwarzania jak i ich eksploatacji technicznej. Szczególne znaczenie ma ten ostatni proces, gdzie ocena wplywu czynników zewnętrznych na prawdopodobieństwo poprawnej pracy wymaga poznania przynajmniej podstawowych wskaźników niezawodności. Zasadniczym celem niniejszego artykułu jest wyznaczenie najsłabszego ogniwa systemu Common Rail, wykorzystujac dane empiryczne oraz dyskretnq symulacje komputerowa.
\end{abstract}

\section{Wstęp}

Konstrukcja silników wysokoprężnych podlega nieustannemu i dynamicznemu rozwojowi. Zwiększenie efektywności ich pracy a tym samym poprawa parametrów eksploatacyjnych jest osiagane przede wszystkim dzięki właściwej ingerencji w układy wtryskowe. Największe znaczenie z uwagi na możliwości rozwoju ma istniejący na rynku motoryzacyjnym już od ponad dziesięciu lat system Common Rail. Jego niewątpliwą przewagą nad innymi rozwiązaniami konstrukcyjnymi jest funkcja rozdzielenia 
procesów wtrysku i wytwarzania wysokiego ciśnienia oraz uniezależnienie ich od prędkości obrotowej silnika. Stwarza to odpowiednie warunki do wytworzenia optymalnej mieszanki, w przypadku której dawka paliwa jest zależna m.in. od wartości momentu obciążającego wał korbowy, położenia pedału przyspieszenia, temperatury silnika i temperatury cieczy chłodzącej. Zapewnienie wysokiej precyzji sterowania dawką paliwa stwarza również korzyści ekologiczne w postaci redukcji toksycznych substancji w spalinach (tlenków azotu, tlenków węgla, węglowodorów i cząstek stałych) i hałasu emitowanego przez silnik. Jest to istotne $\mathrm{z}$ uwagi na zaostrzające się w tym zakresie wymagania.

Wysoki stopień złożoności współczesnych układów wtryskowych generuje problemy związane $\mathrm{z}$ zapewnieniem im wymaganej niezawodności a oczekiwania ich odbiorców są coraz większe. Ponadto w czasach obecnych zauważyć można pewną tendencję dotyczącą wytwarzania obiektów technicznych, która polega na eliminacji obiektów naprawialnych już na etapie ich produkcji. Można wnioskować, że takie zamierzenie ogranicza świadczenie i utrzymanie usług związanych z odnową tych obiektów a więc przynosi pewne korzyści finansowe dla producentów. W związku z tym konieczna staje się znajomość co najmniej podstawowych wskaźników niezawodności, które dla wszystkich elementów danego systemu powinny być identyczne. Jest to oczywiście założenie teoretyczne, które dalece odbiega od rzeczywistości ale stanowi jednak pewien punkt odniesienia dla inżynierów.

Ogólny postęp technologiczny jest jedną z przyczyn, która skłania producentów obiektów technicznych do celowego zmierzenia, jakim jest założenie stosunkowo krótkiego okresu trwałości ale do osiagania wysokiej niezawodności w tym okresie. Wynika to ze świadomości, że w niedługim czasie będzie można wytworzyć ten sam obiekt ale przy znacznie niższych nakładach finansowych. Osiagnięcie wysokiej niezawodności ogranicza nieprzewidziane i niespodziewane przejście obiektu do stanu niezdatności. Jak wiadomo, stanowi to nie tylko problem techniczny ale również ekonomiczny, np. uszkodzenie danego elementu linii produkcyjnej generuje nie tylko nieodwracalne koszty jego wymiany ale także koszty przestoju.

Powyższe problemy projektowania trwałości i niezawodności współczesnych obiektów technicznych stały się podstawą do opracowania metod wspomagania komputerowego, które w oparciu o dane empiryczne pozwalają m.in. wyznaczyć sparametryzowany model matematyczny służący do opisu niezawodności określonych obiektów, a także prowadzić dyskretną symulację ich czasu poprawnej pracy.
Niniejszy artykuł jest etapem procesu analizy niezawodności układu wtryskowego typu Common Rail, polegającym na wykorzystaniu metod symulacji komputerowej do wyznaczenia najsłabszego ogniwa w tym układzie.

\section{Obiekt analizy}

Obiektem analizy jest układ wtryskowy typu Common Rail, eksploatowany w określonej populacji pojazdów samochodowych (obiekty jednorodne) i przedstawiony w postaci schematu funkcjonalnego na ryc. 1 . Przedstawiony system Common Rail był poddany badaniu w aspekcie jego niezawodności, które prowadził autoryzowany serwis pojazdów samochodowych. Wybrano reprezentatywną próbkę 90 pojazdów oraz założono okres badania od chwili wprowadzenia ich do eksploatacji do osiagnięcia wartości przebiegu wynoszącej $120000 \mathrm{~km}$. Jako poprawną prace przyjęto funkcję zasilania paliwem silnika wysokoprężnego zgodnie z przeznaczeniem, do którego został stworzony. W chwili zgłoszenia pojazdu do serwisu z powodu niezdatnego układu wtryskowego, rejestrowano wartość przebiegu tego pojazdu odpowiadającej zauważeniu przez prowadzącego niepoprawnego funkcjonowania układu zasilania paliwem i dokonywano identyfikacji uszkodzonego elementu. Po zakończeniu badania zebrano dane dotyczące występowania niezdatności w badanym układzie wtryskowym. Przyjęto, że elementy które nie uległy uszkodzeniu w założonym okresie eksploatacji nadzorowanej zostały pominięte $\mathrm{w}$ dalszej analizie. $\mathrm{Na}$ podstawie schematu funkcjonalnego (ryc. 1) oraz znajomości zasady działania systemu Common Rail przyjęto szeregową strukturę niezawodnościowa, zakładając że wystąpienie niezdatności dowolnego elementu tego systemu powoduje niezdatność całego układu. Jest to zgodne $\mathrm{z}$ zasadą parisomonii, wedle której eliminuje się elementy zbędne dla poprawnego funkcjonowania obiektu technicznego i ogranicza do minimum nadmiarowość strukturalną.

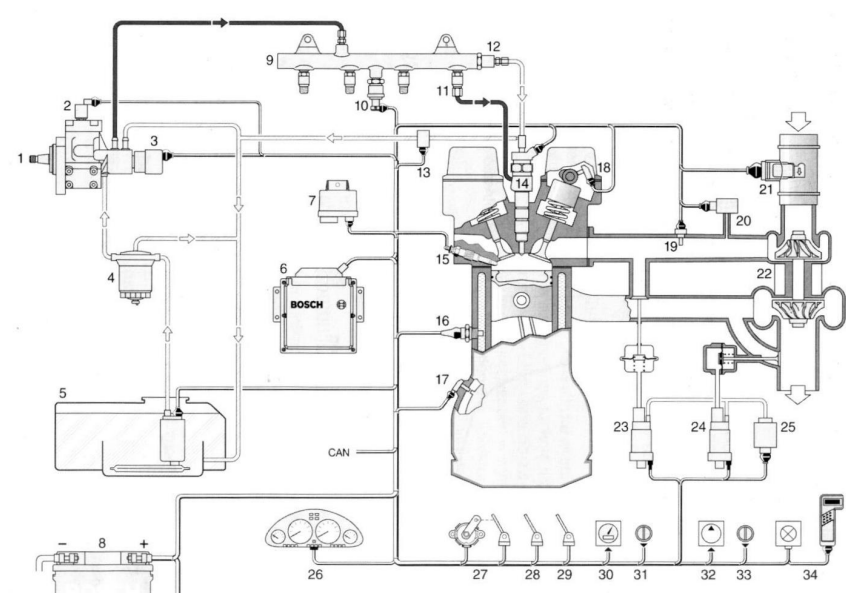

Ryc. 1. Schemat funkcjonalny badanego układu wtryskowego 
1 - pompa wysokiego ciśnienia, 2 - zawór elektromagnetyczny wyłaczania sekcji tłoczacej, 3 -zawór regulacyjny ciśnienia, 4 - filtr paliwa, 5 - zbiornik paliwa z filtrem wstępnego oczyszczania i pompq zasilajaca, 6-sterownik silnika, 7-sterownik świec żarowych, 8-akumulator, 9 - zasobnik paliwa wysokiego ciśnienia, 10 -czujnik ciśnienia listwy paliwowej, 11 -ogranicznik przepływu, 12 - zawór redukcyjny ciśnienia, 13 -czujnik temperatury paliwa, 14 - wtryskiwacz, 15 - świeca żarowa, 16 - czujnik temperatury cieczy chłodzqcej, 17 - czujnik prędkości obrotowej watu korbowego, 18 - czujnik prędkości obrotowej watu rozrzadu, 19 - czujnik temperatury zasysanego powietrza, 20 czujnik ciśnienia doładowania, 21 - masowy przeptywomierz powietrza, 22 - turbosprężarka, 23 - nastawnik recyrkulacji spalin, 24 - nastawnik ciśnienia doładowania, 25 - pompa podciśnienia, 26-zestaw wskaźników, 27 - czujnik pedału przyspieszenia, 28 - styczniki hamulców, 29 - wyłacznik sprzęgła, 30 czujnik prędkości jazdy, 31 - zespół właczania regulatora prędkości jazdy, 32 - sprężarka klimatyzacji, 33 - wyłacznik sprężarki klimatyzacji, 34 - lampka kontrolna silnika ze złaczem diagnostycznym.

\section{Metodyka analizy}

Po zgromadzeniu danych eksploatacyjnych (tab. 1) i przyjęciu szeregowej struktury niezawodnościowej, dokonano wyboru dwuparametrycznego rozkładu Weibulla, jako modelu matematycznego opisującego niezawodność systemu Common Rail i jego elementów oraz dokonano estymacji parametrów tego modelu metodą największej wiarygodności (Maximum Likelihood). W oparciu o zależność (1) wyznaczono charakterystyki funkcji gęstości prawdopodobieństwa elementów układu wtryskowego, które posłużą do weryfikacji wyników poszukiwania najsłabszego ogniwa.

$$
f(t)=\frac{\beta}{\eta}\left(\frac{t}{\eta}\right)^{\beta-1} e^{-\left(\frac{t}{\eta}\right)^{\beta}}
$$

$\beta$ - parametr kształtu

$\eta$-parametr skali
Wykorzystując wskaźnik RI, dostępny w aplikacji BlockSim 7, ukazano wpływ niezawodności poszczególnych elementów układu Common Rail na niezawodność całego systemu. Wskaźnik ten jest obliczany wg następującej zależności:

$$
R I(t)=\frac{R_{s}(t)}{R_{C}(t)} \cdot 100 \%
$$

$R_{S}(t)$ - Prawdopodobieństwo poprawnej pracy systemu w chwili $t$

$R_{c}(t)$ - Prawdopodobieństwo poprawnej pracy elementu w chwili $t$

Na podstawie danych eksploatacyjnych z powyższej tabeli, w aplikacji Weibull++ przeprowadzono analizę danych uciętych prawostronnie (right censored data).

\section{Analiza wyników badania}

Wyznaczone wartości parametrów rozkładu Weibulla dla poszczególnych elementów układu Common Rail zostały przedstawione w tabeli 2 .

Dane eksploatacyjne niezawodności elementów badanego systemu Common Rail

Tabela 2

\begin{tabular}{|c|c|c|r|}
\hline Lp. & Element & $\begin{array}{c}\text { Parametr kształtu } \\
\beta\end{array}$ & Parametr skali $\eta$ \\
\hline 1 & $\begin{array}{c}\text { Pompa wyso- } \\
\text { kiego ciśnienia }\end{array}$ & 1,037757111 & 581505,7292 \\
\hline 2 & $\begin{array}{c}\text { Czujnik ciśnie- } \\
\text { nia listwy paliwo- } \\
\text { wej }\end{array}$ & 0,3826203343 & 2421522782 \\
\hline 3 & Wtryskiwacz & 0,8319327419 & 142610,7325 \\
\hline 4 & $\begin{array}{c}\text { Czujnik obro- } \\
\text { tów wału rozrządu }\end{array}$ & 1,480844914 & 1555811,66 \\
\hline 5 & $\begin{array}{r}\text { Przepływomierz } \\
\text { powietrza }\end{array}$ & 2,380131533 & 590691,7041 \\
\hline 6 & $\begin{array}{c}\text { Czujnik ciśnie- } \\
\text { nia doładowania }\end{array}$ & 1,266713202 & 2395687,432 \\
\hline 7 & Świeca żarowa & 1,00172576 & 1476937,402 \\
\hline
\end{tabular}

Dane eksploatacyjne niezawodności elementów badanego systemu Common Rail

\begin{tabular}{|c|c|c|}
\hline Lp. & Element & $\begin{array}{c}\text { Wartości przebiegów pojazdów w chwili wystapienia uszko- } \\
\text { dzenia elementu }[\mathrm{km}]\end{array}$ \\
\hline 1 & $\begin{array}{l}\text { Pompa wysokiego } \\
\text { ciśnienia }\end{array}$ & $\begin{array}{c}3267,4360,8560,31598,42010,55130,58690,68523, \\
77512,82560,87894,91230,96100,96660,103235,104628\end{array}$ \\
\hline 2 & $\begin{array}{l}\text { Czujnik ciśnienia } \\
\text { listwy paliwowej }\end{array}$ & 4560,16240 \\
\hline 3 & Wtryskiwacz & $\begin{array}{c}1200,1870,3560,3700,4134,4250,4967,5320,5380, \\
6890,7100,7120,8823,11300,12000,12500,14670,16220, \\
18460,21300,23670,25330,29450,34020,34960,42870, \\
43870,47890,48950,51345,53235,57890,61230,69270, \\
73110,82560,84930,86000,87456,91560,93256,96589, \\
97850,96320,99640,102560,102980,104930,105623, \\
106980,108963,110256,114896\end{array}$ \\
\hline 4 & $\begin{array}{l}\text { Czujnik obrotów } \\
\text { wału rozrządu }\end{array}$ & 39000,94850 \\
\hline 5 & $\begin{array}{l}\text { Przepływomierz } \\
\text { powietrza }\end{array}$ & 64000,96520 \\
\hline 6 & $\begin{array}{l}\text { Czujnik ciśnienia } \\
\text { doładowania }\end{array}$ & 52340,56000 \\
\hline 7 & Świeca żarowa & $9650,9856,10230,56890,58456,86540,103460$ \\
\hline
\end{tabular}

Tabela 1 
Poniżej przedstawiono porównawcze charakterystyki gęstości prawdopodobieństwa elementów systemu Common Rail w funkcji przebiegu badanych pojazdów.

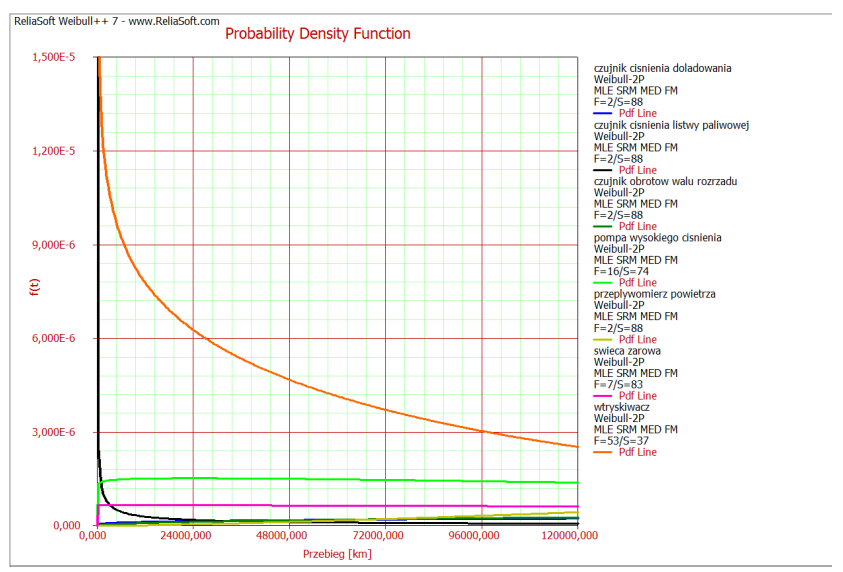

Ryc. 2. Charakterystyki gęstości prawdopodobieństwa elementów systemu Common Rail

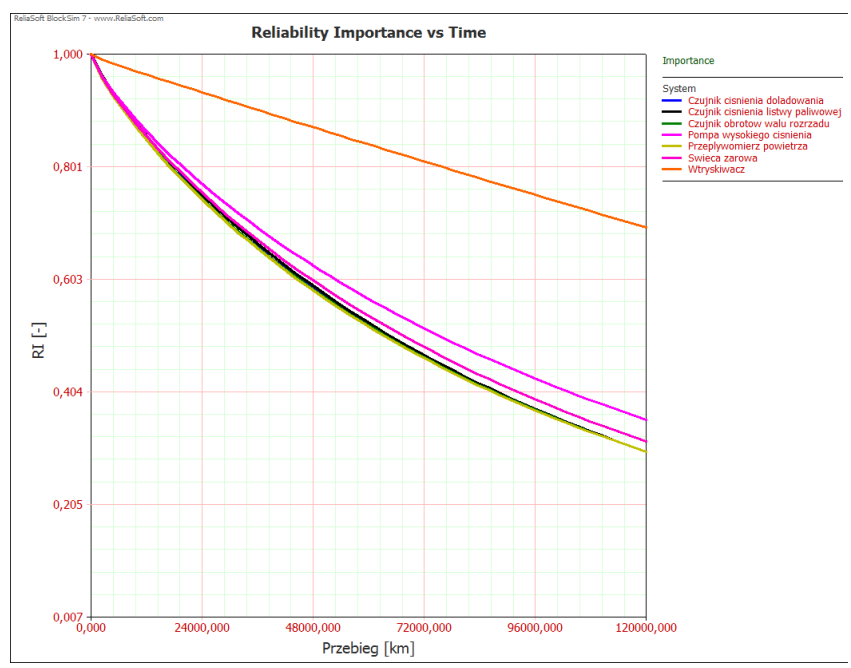

Ryc.3. Charakterystyki Reliability Importance elementów systemu Common Rail

Analizując przebiegi funkcji gęstości prawdopodobieństwa oraz przebiegi charakterystyki wskaźnika RI elementów systemu Common Rail, można stwierdzić że największy wpływ na poprawną pracę tego systemu mają wtryskiwacze. Przyjmowane przez obie funkcje wartości dla wtryskiwaczy są wyraźnie większe niż w przypadku charakterystyk pozostałych elementów. Nie ulega zatem wątpliwości, że wtryskiwacze są najsłabszymi ogniwami badanego systemu. Sa to elementy wykonane $\mathrm{z}$ zachowaniem szczególnej precyzji, których niezawodność jest w znacznym stopniu zależna od jakości zastosowanego paliwa. Obecność substancji niepożądanych w oleju napędowym może powodować m.in. zatykanie się filtra paliwa i częściowe zanieczyszczenie układu wtryskowego. Ponadto, tendencje prowadzące do zwiększania ciśnienia wtrysku a tym samym temperatury pracy wtryskiwaczy mają negatywny wpływ na wytrzymałość cieplną tych elementów, które tracą swoje własności.
Porównując charakterystyki Reliability Importance elementów systemu Common Rail można zauważyć pewne rozbieżności pomiędzy ich przebiegami. Świadczą one o niedoskonałościach układu wtryskowego z punktu widzenia jego niezawodności i są jednocześnie dowodem na dążenie do jej optymalizacji.

\section{Podsumowanie}

W niniejszym artykule dokonano analizy niezawodności układu wtryskowego typu Common Rail na podstawie danych empirycznych, udostępnionych przez autoryzowany serwis pojazdów samochodowych. Metodą największej wiarygodności oszacowano parametry rozkładu Weibulla dla wybranych elementów układu wtryskowego a następnie wygenerowano porównawcze charakterystyki gęstości prawdopodobieństwa i porównawcze charakterystyki wskaźnika RI. Analiza wykazała, że najsłabszymi ogniwami układu Common Rail są wtryskiwacze.

Mając na uwadze wysoki stopnień złożoności współczesnych obiektów technicznych oraz fakt, iż rzetelna analiza niezawodności wymaga operowania na wielu danych, coraz większe znaczenie zyskują aplikacje komputerowe, które wspomagają modelowanie procesów i systemów $\mathrm{z}$ wykorzystaniem zarówno struktur niezawodnościowych jak i fizyki drzewa uszkodzeń.

\section{Literatura}

[1] Kaczor G., Analiza niezawodności uktadu wtryskowego typu Common Rail. Praca dyplomowa magisterska, Kraków $2011 r$.

[2] Manzini R., Regattieri A., Pham H., Ferrari E.: Maintenance for Industrial Systems. Springer-Verlag Gmbh, 2010.

[3] Migdalski J. (red): Inżynieria niezawodności. Poradnik. Wydawnictwo ATR Bydgoszcz - Zetom Warszawa, Warszawa 1992.

[4] Life Data Analysis Reference. Weibull++ 7. Reliasoft Corporation. Tucson AZ USA 1999-2007.

[5] System Analysis Reference. Reliability, Availability \& Optimization. BlockSim 7. Reliasoft Corporation. Tucson AZ USA 1999-2007. 